\title{
Counseling Process in Ductal Carcinoma In Situ
}

\author{
Gheorghe Peltecu ${ }^{1,2}$, Nicolae Gica ${ }^{1,2^{*}}$, Anca Maria Panaitescu ${ }^{1,2}$ \\ "'Carol Davila" University of Medicine and Pharmacy, Bucharest, Romania \\ 2"Filantropia” Clinical Hospital, Bucharest, Romania
}

*Corresponding author: Nicolae Gica, MD

"Carol Davila" University of Medicine and Pharmacy, Bucharest, Romania "Filantropia" Clinical Hospital Bucharest, Romania E-Mail: gica.nicolae@umfcd.ro

\section{Rezumat}

Carcinomul ductal in situ (CDIS) este un grup heterogen de proliferări intraductale, fără o istorie naturală şi o predictibilitate cunoscută şi fără a fi considerat un precursor obligator al cancerului ductal invaziv. Absenta markerilor biologici de predictibilitate face evoluția sa incertă. Deoarece CDIS nu este un precursor obligator al cancerului mamar invaziv, consilierea nu va fi făcută ca pentru un cancer invaziv. Consilierea trebuie să recunoască incertitudinea progresiei către boala invazivă şi fiecare pacientă trebuie corect şi empatic informată astfel încât ea să fie cât mai implicată în procesul de luare a deciziilor.

Cuvinte cheie: carcinom ductal in situ, tratament, consiliere

\begin{abstract}
Ductal carcinoma in situ (DCIS) is a heterogenous group of intraductal proliferations, without a known natural history and predictability and without being considered an obligatory precursor of invasive ductal cancer. Lack of biological markers of predictability makes its evolution uncertain. Because DCIS is not an obligatory precursor of invasive breast cancer, counselling will not be made like in invasive cancer. Counselling must recognize the uncertainty of progression toward invasive disease and every patient must be correctly and empathically informed so that she is as involved as possible in the decision-making process.
\end{abstract}

Key words: ductal carcinoma in situ, treatment, counseling 


\section{Introduction}

Ductal carcinoma in situ (DCIS) emerged in the field of breast pathology and in the concern of patients after the introduction of mammographic screening in the early 1980's. Ductal carcinoma in situ is a heterogenous group of preinvasive neoplastic lesions localized to the lumen of breast ducts. More than 50,000 women are diagnosed with DCIS in the USA each year and statistics estimate that this represents around $18-20 \%$ of the total number of newly diagnosed breast cancers (1).

Ductal carcinoma in situ is variously presented to patients as a precancer, preinvasive disease, non-invasive or stage 0 breast cancer.

The natural history of DCIS is not known, and it is difficult to individualize the evolution of a particular patient. Some patients could have a slowly growing disease (low-grade DCIS) while others have a rapidly growing one (high risk DCIS), and even metastasize to distant organs $(2,3)$.

Given that there are no credible prognostic factors and due to clinicians' and patients' concern about the potentially aggressive nature of the disease, clinicians tend to recommend invasive attitudes consisting of conservative surgery or mastectomy associated with radiation and hormone therapy (4). The need to discover biological or clinical markers is imperative in order to identify those cases that predict the progress to invasive cancer and personalize their management (5).

\section{Methods to Counsel}

Informed consent for clinical treatment is a mandatory process of today's medical practice. It covers three different purposes in three different possible situations: legal, ethical, and administrative (6).

Informed consent process has many facets. The most important factors that influence its success are patient comprehension and time and availability of the physician to provide information and answer patient's questions. Comprehension, in most cases, is overrated.
It should be correlated with age, intelligence, education, status of cognitive functions and anxiety (6).

There are wide variations in clinical practice. Over-treatment of patients with low-risk DCIS is a matter of concern because from the patient's point of view there are psychological consequences related to the effect of disease labeling and a reduced quality of life (unnecessary treatment, alteration of body image) and from the health care system's side, there is a waste of resources $(7,8)$. A very sad experience of overtreatment was presented by a patient herself and consisted of two wide local excisions, one mastectomy, one reconstruction, five weeks of radiotherapy, chronic infection of the donor site, four bouts of cellulitis at the donor site, one nipple reconstruction, seven general anesthetics and more than a year off work. She compared herself to a friend having the same diagnosis, but treated by lumpectomy and radiation therapy, returning to work after 6 months (9).

Treatment decision-making today is determined by the radiological and clinical aspect of the tumor and its prognostic significance. Because breast cancer-specific mortality related to the treatment modalities is low $(10,11)$, and prognosis is excellent, it would be a natural decision to include the patient in the decision-making process $(6,11)$.

Patient's involvement in deciding about the treatment of DCIS can be stressful. It could be difficult, at the same time, because of the complex medical information related to the benefits of treatment and its side effects and prognosis. Sharing a large amount of information, sometimes contradictory, is difficult for the medical personnel because some patients could have difficulties in understanding all information provided $(8,12,13)$.

Many aspects have to be taken into consideration in the counseling process for DCIS. Many women never heard of DCIS and are reluctant to accept that a breast cancer is symptomless $(14,15,16)$. Thus, they have to receive adequate information explaining that DCIS is a precancer state and the aim of the 
treatment, when necessary, is to prevent invasive disease $(17,18)$. Ductal carcinoma in situ has not a known natural history and therefore physicians or nurses doing counseling will be in a difficult position when talking about the uncertainty of progression to invasive disease. Women tend to react as in unfamiliar situations, taking all the precautionary measures, overestimating risk, and choosing the most aggressive treatments. The person offering counseling should try to help the patient make a decision, by showing that a "wait and see" attitude might have a higher benefit.

Studies published in the literature showed that many women are unhappy because of inadequate and conflicting information about DCIS $(8,15,16,17)$. The most stressful and contradictory information is the paradox that for a condition that might never evolve to breast cancer, a mastectomy is recommended (16).

Most studies showed that the most trusted person doing the medical counseling process is the surgeon. She/he had a key role in reducing anxiety and gain trust and professional respect (14).

Women diagnosed with DCIS, waiting to take an informed decision about treatment, want to receive specific information about what DCIS is ("not a real cancer", "lucky cancer", "between normal and cancer"), what are the differences between low and highgrade histological types, uncertainty about its evolution and if individual risk could be predicted $(15,16,19)$. In the case when a decision to treat was taken, women want to receive information about the reason to choose between conservative treatment or mastectomy, if radiation therapy and/or endocrine therapy should be beneficial and why different surgeons recommend different treatment modalities for apparently similar cases (16).

All members of the counseling team should share the same opinion about how to manage DCIS, showing cohesion and avoiding contradictory information. The same coherence should define the information contained in leaflets or posted on the website of the medical institutions.
In the future, in Romania, a key role might be played by a specialized nurse in the field of breast cancer. She will be trained to provide information and emotional support (15), being able to answer questions, showing compassion and respect $(20,21)$, consolidating the information offered by the other members of the team and encouraging the patient to make the right decision. A woman nurse is likely to be more trusted by patients.

The clarity of information offered by all members of the team will have a decisive influence on treatment decisions. Women who perceived risk and benefits of surgical treatment as being equal, will choose conservative treatment instead of mastectomy (22). On the contrary, women who will perceive risk of DCIS to evolve to invasive cancer, will choose mastectomy $(15,18,20,22,24,25,26)$.

Other factors influencing treatment decisions are family history and the perception of team unity. Therefore, if a woman with DCIS has a family history of breast cancer, she will choose a radical surgery $(15,25,26)$. Women would be helped to take an informed treatment decision if all members of the team spoke the same language. They prefer and appreciate those health care providers who treat them as individuals, with respect and empathy and do not speak paternalistic or using too many statistics (14).

An increasing number of patients try to obtain more information from the internet, to complete knowledge about their diagnosis. Credibility of the sources is very different, and patients do not have the knowledge to select them. Academic websites and cancer charities are the most trusted but even here patients have difficulties in understanding because the terminology used by health care providers is sometimes inconsistent (27).

Counseling takes time from busy clinical activity. Studies suggest that surgeons rarely have the adequate time to inform and answer questions to the patient to obtain informed consent. Thus, additional time should be provided to patients in case of unanswered questions. For this additional time nurses specialized in this particular field or surgeons 
from the outpatient clinic could be involved (6).

Counseling should be documented by clinicians to prove they made the effort to inform the patient to take the best decision (6).

\section{Conclusion}

DCIS is still a confusing diagnosis because it has not a known natural history and its natural progression is not predictable.

Because breast cancer-specific mortality related to the treatment modality is low and prognosis is excellent, it is reasonable to involve patients in the decision makingprocess. Counseling needs time and has to be offered by all members of the team treating patients with DCIS. Members of the team involved in counseling have to share the same opinions related to DCIS, avoiding contradictions and giving patients the perception of unity. Counseling must be documented.

\section{Conflict of Interest}

The authors declare no conflicts of interests.

\section{Reference}

1. Ward EM, DeSantis CE, Lin CC, Kramer JL, Jemal A, Kohler B, et al. Cancer statistics: breast cancer. CA Cancer J Clin. 2015;65(6):481-95

2. Roses RE, Arun BK, Lari SA, Mittendorf EA, Lucci A, Hunt KK, et al. Ductal carcinoma-in-situ of the breast with subsequent distant metastasis and death. Ann Surg Oncol. 2011;18(10):2873-8.

3. Ryser MD, Weaver DL, Zhao F, Worni M, Grimm LJ, Gulati R, et al. Cancer outcomes in DCIS patients without locoregional treatment. J Nat Cancer Inst 2019;111(9):952-960

4. Worni M, Akushevich I, Greenup R, Sarma D, Ryser MD, Myers ER, et al. Trends in treatment patterns and outcomes for ductal carcinoma in situ. J Natl Cancer Inst. 2015;107(12):djv263.

5. Groen EJ, Elshof LE, Visser LL, Rutgers EJT, Winter-Warnars HAO, Lips EH, et al. Finding the balance between over- and under-treatment of ductal carcinoma in situ (DCIS). Breast. 2017;31:274-283. Epub 2016 Sep 23.

6. Hall DE, Prochazka AV, Fink AS. Informed consent for clinical treatment. CMAJ, 2012:18(5):533-540.

7. McCaffery KJ, Jansen J, Scherer LD, Thornton H, Hersch J, Carter SM, et al. J. Walking the tightrope: communicating overdiagnosis in modern healthcare. BMJ. 2016; 352:i348.

8. Rutherford C, Mercieca-Bebber R, Butow P, Wu JL, King MT. Treatment decision-making in ductal carcinoma in situ: a mixed methods systematic review of woman's experiences and information needs. Patient Educ Couns. 2017:100(9):1654-1666

9. Flanders J. Breast screening. Reality of ductal carcinoma in situ. BMJ. 2009;338:b958

10. A. Narod SA, Iqbal J, Giannakeas V, Sopik V, Sun P. Breast cancer mortality after a diagnosis of ductal carcinoma in situ. JAMA Oncol. 2015:1(7): 888-96.

11. Allegra CJ, Aberle DR, Ganschow P. Hahn SM, Lee CN, Millon-Underwood $\mathrm{S}$, et al. National institutes of health state-of-the-science conference statement: diagnosis and management of ductal carcinoma in situ September 22-24, 2009. J Natl Cancer Inst. 2010;102(3):161-9.

12. Schofield PE, Butow PN. Towards better communication in cancer care: a framework for developing evidence-based interventions. Patient Educ Couns. 2004;55(1):32-9.

13. Jagsi R, Hayman J. Informing patient decisions regarding management of ductal carcinoma in situ. J Natl Cancer Inst. 2013;105(11):758-9.

14. M. Brown, T. Koch, C. Webb, Information needs of women with noninvasive breast cancer. J Clin Nurs. 2000;9(5):713-722.

15. Napoles-Springer AM, Livaudais JC, Bloom J, Hwang S, Kaplan CP. Information exchange and decision making in the treatment of Latina and white women with ductal carcinoma in situ. J Psychosoc Oncol. 2007; 25(4):19-36

16. Prinjha S, Evans J, Ziebland S, McPherson A. A mastectomy for something that wasn't even truly invasive cancer. Women's understandings of having a mastectomy for screen-detected DCIS: a qualitative study. J Med Screen. 2011;18(1):34-40.

17. De Morgan S, Redman S, D'Este C, Rogers K. Knowledge, satisfaction with information, decisional conflict and psychological morbidity amongst women diagnosed with ductal carcinoma in situ (DCIS). Patient Educ Couns. 2011:84(1):62-8. Epub 2010 Aug 9.

18. Davey C, V. White V, C. Warne C, P. Kitchen P, E. Villanueva E, B. Erbas B. Understanding a ductal carcinoma in situ diagnosis: patient views and surgeon descriptions. Eur J Cancer Care (Engl). 2011;20(6):776-84.

19. Priniha S, Evans L, McPherson A. Women's information needs about ductal carcinoma in situ before mammographic screening and after diagnosis: a qualitative study. J Med Screen. 2006;13(3):110-4.

20. Kennedy F, Harcourt D, Rumsey N. The challenge of being diagnosed and treated for ductal carcinoma in situ (DCIS). Eur J Oncol Nurs. 2008; 12(2):103-11. Epub 2007 Nov 26

21. De Morgan S, Redman S, White KJ, Cakir B, Boyages J. Well, have I got cancer or haven't? The psycho-social issues for women diagnosed with ductal carcinoma in situ. Health Expect. 2002;5(4):310-8

22. Katz SJ, Lantz PN, Zemencuk KJ. Correlates of surgical treatment type for women with noninvasive and invasive breast cancer. J Womens Health Gend Based Med. 2001:10(7):659-70.

23. Wong ST, Chen W, Bottorff JL, Hislop TG. Treatment decision making among Chinese women with DCIS. J Psychosoc Oncol. 2008:26(4):53-73.

24. Katz SJ, Lantz PM, Janz NK, Fagerlin A, Schwartz K, Liu L, et al. Patterns and correlates of local therapy for women with ductal carcinoma-in-situ. J Clin Oncol. 2005;23(13):3001-7.

25. Kaplan CP, Napoles AM, Hwang ES, Bloom, Stewart S, Nickleach D, et al. Selection of treatment among Latina and non-Latina white women with ductal carcinoma in situ. J Womens Health (Larchmt). 2011;20(2):215-23. Epub 2010 Dec 3.

26. Livaudais JC, Hwang ES, Karliner, Napoles A, Stewart S, Bloom J, Kaplan CP. Adjuvant hormonal therapy use among women with ductal carcinoma in situ. J Womens Health (Larchmt). 2012;21(1):35-42. Epub 2011 Sep 8.

27. Fallowfield L, Matthews L, Francis A, Jenkins V, Rea D. Low-grade Ductal Carcinoma in situ (DCIS): How best to describe it? Breast. 2014;23(5):693-6. 